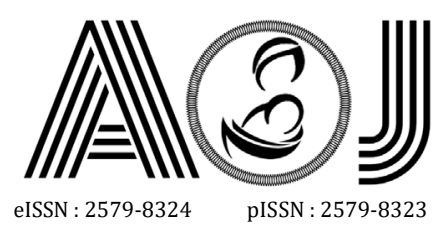

eISSN : 2579-8324
pISSN : 2579-8323

\title{
RESEARCH
}

\section{Differences of Main Levels of Serum P-Selectin and Trombosite in Severe Preeclampsia and Eclampsia}

\author{
Joserizal Serudji ${ }^{1}$, Yudha Meiriza Kartika², Erkadius $^{3}$
}

Affiliations : 1. Sub Division of Maternal Fetal Medicine, Obstetrics and Gynecology Department, Faculty of Medicine, Andalas University, Dr. M. Djamil Central General Hospital Padang; 2. Resident of Obstetrics and Gynecology, Faculty of Medicine, Andalas University, Dr. M. Djamil Central General Hospital Padang; 3. Physiology Department, Faculty of Medicine, Andalas University Padang

Correspondence: Joserizal Serudji, email: jrserudji@yahoo.com, Hp: 08126604980

\begin{abstract}
Preeclampsia-eclampsia is a main complication of pregnancy in which the incidence is increasing world-wide and is associated with maternal morbidity and mortality. P-selectin (CD62P) is released from the cell surface and circulation as soluble molecules in the plasma. Both forms of, as membrane and soluble forms, p-selectin is an agonist of the process of thrombosis and inflammation. This research was conducted by cross sectional method in maternity emergency room of obstetrics and gynecology department of Central General Hospital of Dr. M. Djamil Padang from June 2015 through the sample size is met with 20 patients of severe preeclampsia and 8 patients of eclampsia, who met the inclusion criteria and there is no exclusion criteria. Then performed statistical analysis using t-test to determine differences in mean serum levels of p-selectin and platelet of severe preeclampsia and eclampsia. Differences in mean serum levels of p-selectin and plate-let in the two groups were statistically significant $(p=0.000)$. Activated platelets at eclampsia is higher than severe preeclampsia, which is indicated by the high levels of p-selectin serum and low platelets remaining in eclampsia than severe preeclampsia.
\end{abstract}

Keywords: P-selectin, Platelet, Severe Preeclampsia, Eclampsia

\section{INTRODUCTION}

Preeclampsia is defined as a condition for hypertension ( $\geq 160 / 110 \mathrm{mmHg}$ ) with or without proteinuria may be accompanied by other preeclampsia syndromes after 20 weeks of gestation. Preeclampsia is a major pregnancy complication which is increasing in incidence worldwide and is associated with maternal morbidity and mortality. Eclampsia is a seizure condition in women with preeclampsia that is not caused by other causes. Preeclampsia and eclampsia are the causes of $30-40 \%$ of perinatal deaths in Indonesia. ${ }^{1,2}$

P-selectin (CD62P) is released from the cell surface and circulation as a dissolved molecule in plasma. Both forms are good shape membrane and its dissolved form, $p$-selectin is an agonist of thrombotic and inflammatory processes. Furthermore, CD62P supports platelet interactions and plays a role in early stage inflammation, thrombosis, and atherosclerosis by mediating plaque formation and development. Although p-selectin is present in throm-platelets and endothelial cells, some researchers have concluded that 


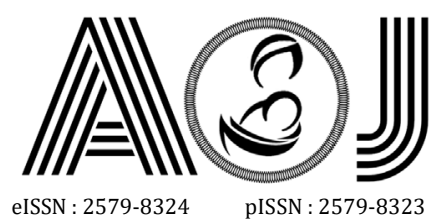

eISSN : 2579-8324
pISSN : 2579-8323

Ruang Redaksi Andalas Obstetrics and Gynecology Journal, Lantai 3 PPDS Obstetri dan Ginekologi Universitas Andalas, RSUP DR. M. Djamil Padang, Jl. Perintis Kemerdekaan Padang, Sumatera Barat 25127

Website:

http://jurnalobgin.fk.unand.ac.id/index.php/JOE

platelets are the main source of pselectin in plasma. Anti-p-selectin antibodies have demonstrated inhibition against thrombus formation, suggesting evidence that $p$-selectin plays a role in thrombosis.

The author is interested in conducting research to determine the number of platelets that experience aggregation by knowing the serum p-selectin level because platelets are the main source of $p$-selectin.

\section{METHOD}

This research is a cross sectional study. Sampling was done by consecutive sampling on patients at RSUP Dr. M. Djamil Padang from June to November 2015 who met the inclusion criteria and no exclusion criteria were obtained, until the number of samples was met. This study used the t-test to determine the significance of the differences between the two means.

\section{RESULTS}

\section{Characteristics of Research Samples}

Of the 28 samples, the characteristics of the study sample were based on age, gravida, and gestational age as shown in Table 1 . The mean age of the severe preeclampsia group was higher than the mean value in the group of eclampsia patients, it was $33.9 \pm 4.3$ years: $26.9 \pm$ 7.9 years, $p=0.005$. This shows that there is a difference in the mean age of patients with severe preeclampsia and eclampsia.

The mean gravida value of the severe preeclampsia group was higher than the mean value in the eclampsia group, which was $2.4 \pm 1.1: 2.0 \pm 1.8, p=0.537$. This shows that the gravida in patients with severe preeclampsia is equivalent to eclampsia.

The mean value of gestational age in patients with eclampsia was lower than the mean value of gestational age in patients with severe preeclampsia, which was $34.1 \pm 3.2$ weeks: $35.0 \pm 4.1$ weeks, $p=0.594$. This shows that the gestational age in patients with severe preeclampsia is equivalent to eclampsia.

Table 1. Characteristics of the Research Sample

\begin{tabular}{cccc}
\hline \multirow{2}{*}{ Characteristics } & \multicolumn{2}{c}{ Groups } & \multirow{2}{*}{-value } \\
\cline { 2 - 3 } & Severe preeclampsia (means \pm SD) & Eclampsia (means \pm SD) & 0,005 \\
Age & $33,9 \pm 4,3$ & $26,9 \pm 7,9$ & 0,537 \\
Gravid & $2,4 \pm 1,1$ & $2,0 \pm 1,8$ & 0,594 \\
Gestational age & $35,0 \pm 4,1$ & $34,1 \pm 3,2$ & \\
\hline
\end{tabular}

\section{Difference in mean serum p-selectin levels in Severe Preeclampsia and Eclampsia}

Based on table 2, it was found that the mean serum pselectin level in eclampsia was higher, namely $241.5 \pm 19.1 \mathrm{ng} / \mathrm{ml}$ compared to the mean serum $p$-selectin level in severe preeclampsia, namely $120.7 \pm 26.9 \mathrm{ng} / \mathrm{ml}$. The results of statistical analysis with t-test 


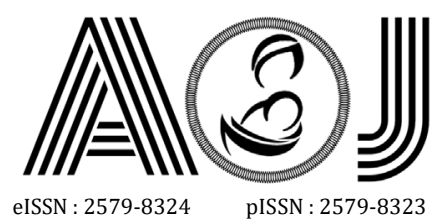

eISSN : 2579-8324

Ruang Redaksi Andalas Obstetrics and Gynecology Journal, Lantai 3 PPDS Obstetri dan Ginekologi Universitas Andalas, RSUP DR. M. Djamil Padang, Jl. Perintis Kemerdekaan Padang, Sumatera Barat 25127

\section{Website:}

http://jurnalobgin.fk.unand.ac.id/index.php/JOE

showed a significant difference in the mean $p$-selectin levels in eclampsia patients with severe preeclampsia, this can be seen from the $p$ value of 0.000 .

Table 2. Differences in Serum P-Selectin Levels in Severe Preeclampsia and Eclampsia

\begin{tabular}{cccc} 
& Severe preeclampsia & Eclampsia & \multirow{2}{*}{-value } \\
& $n=20$ & $n=8$ & \\
\hline Mean & 120,7 & 241,5 & 0,000 \\
SD & 26,9 & 19,1 & \\
\hline
\end{tabular}

\section{Difference in mean platelet levels in severe preeclampsia and eclampsia}

Based on table 3, it was found that the mean platelet levels in severe preeclampsia were higher, namely $263,690 \pm 31,371.9 / \mathrm{mm} 3$ compared to the mean throm-platelet levels in eclampsia, namely $177,875 \pm 83,011.9 / \mathrm{mm} 3$. The results of statistical analysis with t-test showed a significant difference in the mean platelet levels in patients with severe preeclampsia and eclampsia sufferers, this can be seen from the $p$ value of 0.000 .

Table 3. Differences in Platelet Levels in Severe Preeclampsia and Eclampsia

\begin{tabular}{cccc} 
& $\begin{array}{c}\text { Severe preeclampsia } \\
n=20\end{array}$ & $\begin{array}{c}\text { Eclampsia } \\
n=8\end{array}$ & p-value \\
\hline Mean & 263.690 & 177.875 & \multirow{2}{*}{0,000} \\
SD & $31.371,9$ & $83.011,9$ & \\
\hline
\end{tabular}

\section{DISCUSSION}

\section{Characteristics}

The incidence of preeclampsia increases in women over 35 years of age. 2.5 Age under 17 years is strongly associated with eclampsia. 6 In this study, the mean age of the preeclampsia group was $33.9 \pm 4.3$ years, while the mean age in the eclampsia group was $26.9 \pm 7.9$ years. The results of further statistical analysis showed that the age difference between severe preeclampsia and eclampsia patients was significantly different, this can be seen from the $p$ value of 0.005 .

The risk of severe preeclampsia is increased in nulliparous compared to multiparous. ${ }^{2}$ In this study, based on the gravida characteristics, the mean value of the group of patients with severe preeclampsia was $2.4 \pm 1.1$ compared to the mean value in the group of patients with eclampsia which was $2.0 \pm 1.8$. The results of further statistical analysis, the difference in gravida in patients with severe preeclampsia and eclampsia patients did not have a significant difference, this can be seen from the $p$ value of 0.537 .

The risk of preeclampsia increases with increasing gestational age. The incidence of preeclampsia increases at gestational age above 34 weeks. 7 The sample in this study was taken at a gestational age above 20 weeks and the mean value of gestational age in the group 


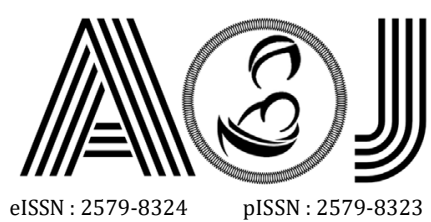

eISSN : 2579-8324
pISSN : 2579-8323
ANDALAS OBSTETRICS AND GYNECOLOGY JOURNAL

Alamat Korespondensi:

Ruang Redaksi Andalas Obstetrics and Gynecology Journal, Lantai 3 PPDS Obstetri dan Ginekologi Universitas Andalas, RSUP DR. M. Djamil Padang, Jl. Perintis Kemerdekaan Padang, Sumatera Barat 25127

Website:

http://jurnalobgin.fk.unand.ac.id/index.php/JOE

with severe preeclampsia was higher, namely $35.0 \pm 4.1$ weeks compared to the mean value in the group of people with eclampsia, namely $34.1 \pm 3.2$ weeks. The results of further statistical analysis, differences in gestational age in patients with severe preeclampsia and patients with eclampsia have insignificant differences, this is seen from the $p$ value of 0.594 .

\section{P-selectin levels}

There was a significant difference in the mean serum pselectin level for those with severe preeclampsia, namely $120.7 \pm 26.9 \mathrm{ng} / \mathrm{ml}$ with the eclampsia group of $241.5 \pm 19.1 \mathrm{ng} / \mathrm{ml}$, $p=0.000$. Preeclampsia is associated with extensive platelet activation. P-selectin exposes microparticles with procoagulant activity released from platelet activation, which can be found in the peripheral blood of preeclamptic women. P-selectin is found to be greater in serum or plasma in preeclampsia. Early acceleration of $p$-selectin represents the onset of asymptomatic disorders of the maternal vascular system. ${ }^{8}$

The increase in p-selectin in preeclampsia seems to confirm that this process occurs in preeclamptic pregnancies. Pselectin levels higher rates of preeclamptic pregnancy suggest that excess circulating pselectin contributes to the pathogenesis of certain pregnancy disorders. P-selectin is an agonist for thrombotic and inflammatory processes, and is considered a marker for activation of platelets and endothelium as well as inducers of procoagulants. P-selectin plays an important role in atherosclerosis and atherosclerotic plaque formation. These results suggest that $p$-selectin may be at least partly responsible for the etiopathogenesis of the maternal preeclampsia syndrome. ${ }^{4,9}$

P-selectin is significantly higher in preeclampsia than in normal pregnancy and nonpregnant women. ${ }^{10}$ Halim (1996) and Chaiwora-pongsa (2002) concluded that there was an increase in p-selectin levels in preeclampsia and eclampsia. Bosio et al. demonstrated a significant increase in plasma $p$-selectin concentrations in preeclamptic women during pregnancy when compared with the normotensive pregnancy and gestational hypertensive populations.

\section{Platelet Levels}

There was a significant difference in the mean serum platelet levels of the severe preeclampsia group, namely $263,690 \pm 31,371.9 / \mathrm{mm} 3$ with the eclampsia group of 177,875 $\pm 83,011,9 / \mathrm{mm} 3, p=0,000$. The data suggest that microvascular inflammation is an important factor contributing to the pathogenesis of preeclampsia. Abnormal placentation is thought to be responsible for the release of microparticles and antiangiogenic factors into the maternal systemic circulation. These soluble factors initiate platelet activation, produce inflammatory cytokines, and vascular endothelial dysfunction.

Although circulating platelets are in a resting state, they are exposed to soluble mediators or microparticles in the vessels 


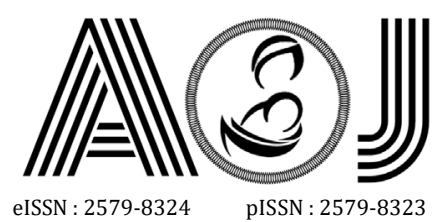

eISSN : 2579-8324
pISSN : 2579-8323

Ruang Redaksi Andalas Obstetrics and Gynecology Journal, Lantai 3 PPDS Obstetri dan Ginekologi Universitas Andalas, RSUP DR. M. Djamil Padang, Jl. Perintis Kemerdekaan Padang, Sumatera Barat 25127

Website:

http://jurnalobgin.fk.unand.ac.id/index.php/JOE

Inflamed blood as in preeclampsia, platelets are activated by binding of mediators to their surface receptors. After activation, platelets release various dissolved and adhesion molecules such as CD40L, the platelet endothelial cell adhesion molecule-1 (PECAM-1 / CD 31). When dissolved diators release into the inflammatory environment they trigger interactions between platelets, leukocytes, and endothelial cells (ECs). Cross-talk between platelets and leucocytes stimulates neutrophil migration to the inflammatory site by forming platelet-leukocyte aggregates. Plateletleukocyte binding increases endothelial permeability and induces production of inflammatory cytokines leading to amplification of morphology and molecular inflammatory responses. ${ }^{14}$

Under normal physiological conditions, circulating platelets are at rest. Healthy vascular endothelium secretes several mediators such as nitric oxide (NO), and adenosine which inhibits platelet activation, adhesion to endothelium. ${ }^{2,13}$ However, inflammation of the endothelium results in the production of these protective mediators being reduced. NO and adenosine metabolites are increased in pre-eclampsia patients in parallel to significant platelet activation compared with normotensive pregnancies.10 Lyall et al. demonstrated that NO concentrations are increased in the feto-placental circulation in preeclampsia. They also suggest that elevated NO levels further complement platelet activation in preeclamptic women. ${ }^{13}$

Circulating platelets are exposed to soluble factors such as lipid mediators, cytokines, and chemokines which are released by activated leukocytes and endothelial cells due to inflammation of the blood vessels. The accumulation of these mediators gives rise to an activation response characterized by degra-nulation of platelet granules. ${ }^{14,15,16}$ Chavarria (2008) states that a higher blood content of $p$-selectin can confirm the presence of activation of thrombocytes and endothelial cells in preeclampsia. ${ }^{17}$

\section{CONCLUSION}

Activated platelets in eclampsia patients are higher than in patients with severe preeclampsia, which is indicated by high serum pselectin levels and low remaining platelets in eclampsia patients compared to severe preeclampsia.

\section{REFERENCES}

1. Roeshadi HR. Hipertensi dalam kehamilan. Dalam: Ilmu Kedokteran Fetomaternal. Edisi 1. Himpunan Kedokteran Fetomaternal Perkumpulan Obstetri dan Ginekologi Indonesia. Surabaya: 2004. 494-500.

2. Cunningham FG, et al. Hypertensive Disorders. Dalam: William Obstetrics: Obstetrical Complications. Edisi 24. The McGraw-Hill Companies, Inc. New York: 2014. 1508-1612.

3. Holmes VA, Wallace JMW, Gilmore WS, dan McFaul P. Soluble P-selectin levels during normal pregnancy: a longitudinal study. BJOG 2002; 109: 997-1002. 


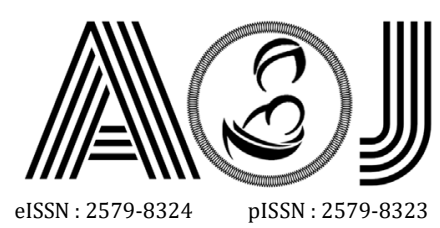

Ruang Redaksi Andalas Obstetrics and Gynecology Journal, Lantai 3 PPDS Obstetri dan Ginekologi Universitas Andalas, RSUP DR. M. Djamil Padang, Jl. Perintis Kemerdekaan Padang, Sumatera Barat 25127

4. Laskowska M, Laskowska $\mathrm{K}$, dan Oleszczuk J. Elevated maternal serum sP-selectin levels in preeclamptic pregnancies with and without intrauterine fetal growth restriction, but not in normotensive pregnancies complicates by isolated IUGR. Med Sci Monit 2013; 19: 118-124.

5. Khalil A, Syngelaki A, Maiz N, Zinevich Y, dan Nicolaides KH. Maternal age and adverse pregnancy outcome: a cohort study. Ultrasound Obstet Gynecol. 2013; 42: 634-643.

6. Abalos E, Cuesta C, Carroli G, Qureshi Z, Widmer M, Vogel JP, dan Souza JP. Preeclampsia, eclampsia, and adverse maternal and perinatal outcomes: a secondary analysis of the World Health Organization Multicountry Survery on Maternal and Newborn Health. RCOG. 2014; 121 (Suppl I): 14-24.

7. Akolekar R, Syngelaki A, Sarquis R, Zvanca M, dan Nicolaides KH. Prediction of early, intermediate, and late pre-eclampsia from maternal factors, biophysical, and bio chemical markers at 11-13 weeks Prenat Diagn. 2011; 31: 66-74. Monte S. Biochemical markers for prediction of preeclampsia: review of the literature. Journal of Prenatal Medicine. 2011; 5 (3): 69-77.

8. Lurie S, Sherman D, Bukovsky I. Omphalocele delivery enigma: the best mode of delivery still remains dubious. European Journal of Obstetrics \& Gynecology and Reproductive Biology 1999:82.

9. Chaiworapongsa $T$, Romero R, and Yoshimatsu J. Soluble adhesion molecule profile in normal pregnancy and preeclampsia. J Matern Fetal and Neonatal Med 2002; 12: 1927.

10. Yoneyama Y, Suzuki S, Sawa R, Power GG, and Araki T. Increased plasma adenosine concentrations and the severity of preeclampsia. Gynecol Obstetrics. 2002; 100 (6): 1266-1270.

11. Halim A, Kanayama N, dan el Maradny E. Plasma p-selectin (GMP-140) and glycocalicin are elevated in preeclampsia and eclampsia: their significances. Am J Obstet Gynecol 1996; 174: 272-277.

12. Bosio PM, Cannon S, McKenna PJ, O'Herlihy C, Conroy R, and Brady H. Plasma Pselectin is elevated in the first trimester in women who subsequently develop preeclampsia. BJOG 2001; 108: 709-715.

13. Sahin S, Ozakpinar OB, Eroglu M, dan Retik S. Platelets in Preeclampsia: Function and Role in the Inflammation. Journal of Marmara University Institute of Health Sciences 2014 ; 4 (2): 111-116.

14. Zarbock A, Polanowska-Grabowska RK, and Ley K. Platelet-neutrophil-interactions: linking hemostasis and inflammation. Blood Rev. 2007; 21 (2): 99-111.

15. Stokes KY dan Granger DN. Platelets: a critical link between inflammation and microvascular dysfunction. J Physiol. 2012; 590(5): 1023-1034.

16. Gear AR dan Camerini D. Platelet chemokines and chemokine receptors: linking hemostasis, inflammation, and host defense. Microcirculation 2003; 10(3-4): 335-350.

17. Chavarría ME, Lara-González L, García-Paleta Y, Vital-Reyes VS, dan Reyes A. Adhesion molecules changes at 20 gestation weeks in pregnancies complicated by preeclampsia. Eur J Obstet Gynecol Reprod Biol. 2008; 137(2): 157-164. 